\title{
Theoretical and Practical Aspects of the Infringement of Myth Hole in Romania
}

\author{
Alexandru Peicea \\ “Alexandru Ioan Cuza” Police Academy, Bucharest, Romania, alexandru.peicea@gmail.com
}

\begin{abstract}
It is widely known that corruption worldwide generates harmful effects, affecting the economy of the whole planet over time, the good development of social relations and the trust of citizens in their own state, governors and civil servants. Taking bribes is one of the most serious offenses under the Romanian Penal Code, which is also the result of the punishment stipulated by the law to be applied to the persons committing such offenses. In order to prevent and combat this harmful phenomenon, the Romanian legislature regulated in a special law higher punishments for committing the bribery offense for persons occupying a certain position in the state or having a certain quality, circumstance which increases the degree of social danger created for social relations protected by the rule of criminalization. This paper aims to deal with the constitutive content of the bribery offense in Romania and to present relevant judicial practice issues in this field.
\end{abstract}

KEYWORDS: bribery, corruption, jurisprudence, punishment

\section{Introduction - Concept, Object and Subjects of the Offence}

The concept of "corruption" has a secular and a legal connotation. The need to criminalize corruption is not a novelty of the present or Romanian society in particular. These crimes have been incriminated ever since the beginnings of human society. The most representative corruption offense has been and continues to be the crime of bribery. The protected social value is the honesty of state officials who do not have to demand or receive any additional benefit for the exercise of public office, nor should they sell the benefit of their status to those who are interested in a particular conduct of their own. It is certain that a corrupt society generates multiple negative effects in terms of its functioning (unfair competition, correct hierarchy of value, etc.). This finding led the legislator to criminalize corruption in the private environment as well. The decision to criminalize corruption in the private environment is also justified by the corruption conventions to which Romania is a party, conventions which have drawn the task of the signatory states to criminalize corruption in this plan. Such a decision is not a matter of novelty, because, including in the previous regulation, corruption in the private environment was incriminated (Bogdan, Șerban, Zlati 2014, 413).

Corruption has existed and has manifested itself since ancient times. Corruption is the greatest enemy of democracy. Conscious of the particularly serious problems that corruption generates over general socio-economic development, the world's states, individually or together, are trying to identify the most effective means of halting it (Voicu and Boroi 2006). The issue of corruption is at the center of public attention in the European Union. The EU, the World Bank and other European institutions regularly assess corruption and its implications on the economic and social level (Dascălu, Ghinea, Negoiță and Moilat 2012, 12).

According to Penal Code enforced on $1^{\text {st }}$ of February 2014 (published in the Official Gazette of Romania No 510 of 24 July 2009), the offence of bribery represents the civil servants' act who, directly or indirectly, for himself or for another person, pretends or receives money or other advantages which are not entitled to him or he accepts the promise for these kind of advantages, for the fulfillment, non-fulfillment, urging or delaying the fulfillment of a task that enters into his duties of service or in connection with the performance of an act contrary to those duties (Article. 289 para. (1) of the Penal Code). It is considered also a bribery offence, the felony committed in connection with the non-fulfillment, the delay in the performance of a service duty or in connection with the performance of an act contrary to that duty performed by the person exercising a service of public interest for which he was vested in the public authorities or which is subject to control or oversight of the fulfilment of that public service (Article. 175 para. (2) of the Penal Code). 
The legal object of the offence is represented by the social relations that impose the interdiction of receiving some amounts of money or other advantages by the civil servants who perform a certain activity that implies the exercise of the state authority. We can declare that, even if the offence of bribery is to be found in the chapter referring to the corruption offences, this is a genuine service offence.

Regarding the physical object of the bribery offence, it should be noted that this cannot have such an object, the money or the undued advantages representing the offence's product and by no means its physical object (Rotaru, Rose and Cioclei 2018, 218). In this sense, it was also ruled the supreme court by Decision no. 1789/2003, according to which "taking bribery doesn't have a physical object because the money or the advantages are object of the bribe and not an object of the offence".

The active subject of the bribery offence is qualified, he may be a public servant, as defined by article 175 of the Penal Code (Udroiu 2014, 342).

Civil servant, for the purposes of criminal law, is that person who is permanently or temporarily, with or without remuneration:

a) Exercises powers and responsibilities, established under the law, in order to achieve the prerogatives of legislative, executive or judicial power.

b) Exercises a function of public dignity or a public function of any kind.

c) Exercises alone, or together with other persons, within the framework of an autonomous direction, of another economic operator, or a legal person with full or majority state capital, tasks related to the performance of the object of its activity. However, the active subject of the offence can also be a private official (The private official is the person described in art. 175 para. (2) of the Penal Code) and under attenuated version, certain civil servants with special status, as referred to in law 78/2000 (Article 7 of Law no 78/2000 refers to persons who: a) exercise a function of public dignity; b) He is a judge or prosecutor; c) It is a criminal investigation body or has a finding or sanctioning of contravention tasks; d) is one of the persons referred to in art. 293 of the Penal code). Thus, they may have the status of civil servant, for the purposes of criminal law, and, therefore, may be considered active subjects of the offence of taking bribes the MPs, ministers, magistrates, those exercising a public office chosen or appointed, the President of Romania, Judges of the Constitutional Court, civil servants from institutions such as the Presidential Administration, the Court of Accounts, the Ombudsman, local elected officials such as mayors, presidents of county councils, but also those occupying positions assimilated to public dignity, teachers, doctors, public notaries, officers of the court, interpreters, translators, administrators and judicial liquidators.

It is to be noted that in relation to the persons who may have the status of an active subject of the bribery offence provided for in art. 7 para. (1) lit. c) of Law no 78/2000, the High Court of Cassation and Justice, in solving the matter of law, decided that: "The provisions of art. 7 para. (1) of law 78/2000 for the prevention, discovery and sanctioning of facts of corruption, shall apply only where the offence of bribery has been committed by the perpetrator in relation to his or her duties of service concerning the finding or penalties" (Decision No 2/25.01.2017).

Regarding the quality of the doctor as active subject of the bribery offence, according to national case-law it is established that "the doctor employed with work contract in a health care institution from the public system, he has the quality of civil servant under the acceptance of articles 175 paragraph (1) letter b) $2^{\text {nd }}$ thesis from Penal Code" (Decision No 26/03.12.2014).

In case the doctor is employed in a private health care institution, he will be responsible for the offence of taking the bribe according to watered-down version foreseen by article 308 of the Penal Code. In the case-law, it has been discussed the issue if the doctor who receives extra payments or donations is an active subject of the bribery offence. The Supreme Court has discussed this problem also, by pronouncing a decision according to which "The public health care practitioner's act, who is a public servant, of receiving additional payments or donations from patients, according to art. 34 paragraph (2) of Law No 46/2003 on the rights of the patient does not constitute an exercise of a right recognised by law that could attract the incidence of art. 21 para. 
(1) of the Penal Code" (Decision No 19/04.06.2015) meets the conditions for the existence of the bribery offence.

The criminal participation is possible in all forms. Thus, a person may be an author, coauthor, instigator or accomplice to the commission of a bribe-making offence. It is important to note that in order to be a co-author, a person must have the quality required by law to respond criminally to the offence.

\section{Constitutive Content of the Bribery Offence}

The objective side of a crime consists of three components: the material element consisting of the action or inaction prohibited by the rule of criminality, the immediate follow-up which represents the dangerous social humiliation laid down in the norm of crimination and the causal link between them.

In the case of a bribery offence, the material element of the objective side consists in claiming, receiving or accepting a promise of money or other undue advantages. The existence of the offence requires the fulfillment of essential conditions attached to the material element. In this respect, a first condition is that the act relates to money or other benefits that are not entitled to the public servant. A second condition relates to the fact that the action or inaction falling within the composition of the material element must be committed in relation to the fulfillment, failure, urgency or delay of the fulfillment of an act entering the duties of service of the active subject or in connection with the performance of an act contrary to those duties.

It is very important to mention the fact that in case it fails to perform the act or it performs an act contrary to his service duties, are considered criminal offences and will not be absorbed into the content of the bribery offence but will be considered a concurrent infringement (It is, for example, the case of the policeman who after taking bribes draws up a report of the finding of a false contravention. In this situation, it is considered a concurrent infringement of bribery and false intellectual and not a single bribe-taking offence). Bribery may be considered a concurrent infringement with influence traffic if the public servant is not confined to receiving money for himself but, following the remitting of money, he also influences other people for the purpose of failure to perform their duties.

Immediate follow-up is a state of danger for the service relationships within the institution or authority where the bribed official operates. The causal link arises from the materiality of the crime.

Subjective side. The offence of bribery is committed with direct or indirect intent. In older practice, the main evidence demonstrating the committing of a bribe-taking offence was setting up a sting operation. Nowadays, the investigating bodies use in the vast majority of cases the denunciation and technical records. It is to be noted that for the conviction of a person it is not sufficient to formulate a denunciation, its non-corrosion with other means of proof, unassuming the presumption of guilt.

In that regard, the Supreme Court, which in a decision ruled that "The presumption of innocence shall be rejected only by the proven certitude of the defendant's guilt. If that certainty does not exist, the presumption of innocence works and is supplemented by the principle that any doubt is interpreted in favour of the defendant" (see Decision No 343/2012).

The offence of taking bribery, being a particularly serious offence, is punishable by imprisonment and moreover, against the public servant may also apply a complementary punishment consisting in prohibiting the exercise of the right to occupy a position or to exercise the profession or activity in which he committed the deed.

\section{Conclusions}

The corruption, being a phenomenon that affects the entire planet is necessary to be combated by implementing at the level of each country some precise punishments. But, even if this phenomenon has reached a very high level, I consider that it is necessary that the states should punish the persons who commit acts of corruption, repeatedly. It's not indicated that in the case where a person commits several acts of corruption to be punished very harshly. In fact, there should be implemented some regulations 
that could stop the application of the so-called giraffe punishments, which are, in fact, penalties of a very high amount which are not justified, in relation to the actual social hazard caused by the committing of criminal offences of corruption.

From my point of view, the taking or giving of bribes could be included in the category of natural crimes, as Cesare Beccaria classifies, these being crimes which, in any social system, could be identified and classified as such. Even if the new criminal code brings a reformulation of the bribery text in an attempt to boost the fight against corruption, in my view, the apparent failure to comply with the EU's obligations to reduce corruption and combat it was not generated by the lack of criminalization texts, but was and is generated by the tolerance of justice and politicians towards this phenomenon. From my point of view, the form of criminalization crimes cannot itself affect the effectiveness of the fight against corruption.

\section{References}

Decision No 343/2012 of the Court of Appeal Craiova, Criminal section and cases with minors.

Decision No 26/03.12.2014, I.C.C.J, Governing board on legal matters in criminal matters, published in the Official Gazette of Romania no 24 of 13 January 2015.

Decision No 19/04.06.2015, I.C.C.J, Governing board on legal matters in criminal matters, published in the Official Gazette of Romania no 590 of 5 August 2015

Decision No 2/25.01.2017, I.C.C.J, Governing board on legal matters in criminal matters, published in the Official Gazette of Romania no 157 of 2 March 2017.

Law No 78/2000 on the prevention, discovery and sanctioning of corruption facts.

Bogdan Sergiu, Șerban Doris Alina, Zlati George. 2014. New Penal Code. The Special Part. Bucharest: Universul Juridic Publishing House.

Dascălu Ioan, Ghinea Nicolae, Negoiță Robert Sorin, Moilat Andreea Luana. 2012. The preventing and combating corruption. Craiova: Sitech Publishing House.

Rotaru Cristina,Trandafir Andra Roxana, Cioclei Valerian, 2018. Criminal Law, Special Part II, Thematic Course. Bucharest: C. H. Beck Publishing House.

The Romanian Penal Code, entered into force on 01 February 2014.

Udroiu Mihail. 2014. Criminal Law. The Special Part. Bucharest: C. H. Beck Publishing House.

Voicu Costică, Boroi Alexandru. 2006. Criminal Law of Affairs. Bucharest: Universul Juridic Publishing House. 